\title{
MODERNIZATION TENDENCIES IN ARCHITECTURE AND STREET INFRASTRUCTURE IN KOSOVO DURING THE TANZIMAT REFORMS
}

\author{
${ }^{1}$ Vlora NAVAKAZI", ${ }^{2}$ Florina JERLIU \\ ${ }^{1,2}$ Department of Architecture, Faculty of Civil Engineering and Architecture \\ University of Prishtina, Bregu i Diellit p.n, Prishtina, Kosovo \\ e-mail: ${ }^{1}$ vlora.navakazi@uni-pr.edu, ${ }^{2}$ florina.jerliu@uni-pr.edu
}

Received 5 October 2018; accepted 10 January 2019

\begin{abstract}
Modernization tendencies in architecture and street infrastructure were introduced in Kosovo during the Tanzimat Reforms, enforced by the Ottoman Empire in the late $19^{\text {th }}$ century. Lack of original archive documentation until now has impeded scientific approach to urban and architectural analysis, for which reason, Kosovo cities often face difficulties in documenting their historical and cultural continuity. In order to fill the gap of knowledge about urban built heritage of $19^{\text {th }}$ century in Kosovo, this paper uses and analyzes original visual archival documents, retrieved by author from the Premiership Ottoman Archives Analyses show that construction of street network and public buildings was realized in line with the needs arising from new administrative division imposed by the Tanzimat Reforms. While street network intended to connect Kosovo settlements, public buildings and especially the government buildings built in Prizren and Prishtina, former centers of Vilayets, intended to introduce new building standards and a new language of architecture. Interrogation of modernization tendencies in architecture and street network in Kosovo during this period is important for establishing a continuity of future planning development, as well as in narrating modernization tendencies that occurred in Kosovo in line with other parts of the Late Ottoman Empire territories in the Balkan.
\end{abstract}

Keywords: Architecture and street network in $19^{\text {th }}$ century, Government buildings, Tanzimat Reforms, Kosovo

\footnotetext{
* Corresponding Author
} 


\section{Introduction}

The Tanzimat Reforms, which were initiated in 1839 aimed to modernize the Ottoman State's political, social and economic structure in line with western tendencies [1, p. 943]. Reforms also brought changes in architecture and urbanism in terms of urban planning provisions, style and function, that aimed at the modernization of cities in the territories of the Ottoman Empire [2, pp. 32-33]. An important aspect of Reforms was the provision of new administrative buildings that ought to accommodate new institutions created as a result of new administrative division into new territorial units called Vilayets (provinces), Sanyaks (sub-regions) and Nahiyes (municipalities). Centres of Vilayets during late $19^{\text {th }}$ century gained new government and military buildings, including other public buildings. First efforts of the Reforms were focused on urban regeneration of the Centers of Vilayets Prishtina, Shkoder, Manastir, Janina, etc, which were seen as promoters of the modernization (Fig. 1). Influenced by the West, the Empire engaged in economic and social changes through changing forms of trade and management of traditional city centers, which slowly began to be shaped into new modern urban centers [2, p. 31]. Apart from representative public buildings, which mainly occupied the former traditional city center, cities gained new wide streets with alleys of trees, influenced by urban panoramas of European capitals like Vienna and Paris [2, p. 49].

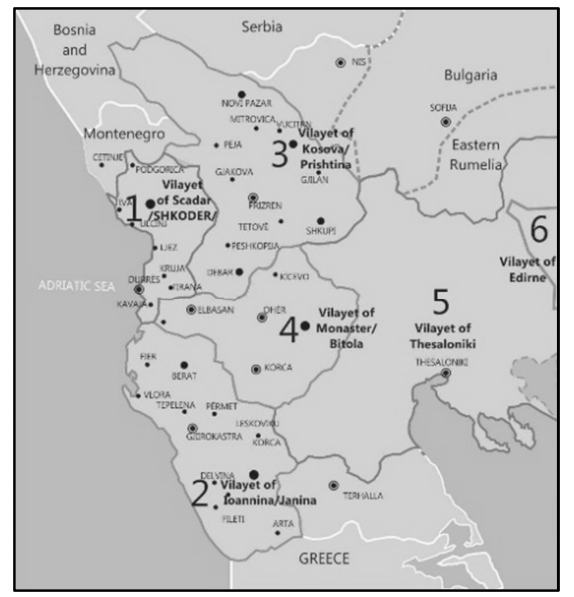

Fig. 1. Vilayets in the European part of the Ottoman Empire (Source: Authors plot, Vlora Navakazi, Florina Jerliu)

Planning regulations adopted during the Tanzimat Reforms were likewise influenced by the West, aiming at finding solutions to emerging issues [3, p. 10] related to understandard narrow streets, building technology and material, etc. The regulation of 1863 about urban planning in the modern sense was among first ones enacted after the Tanzimat Reforms. This regulation of 1863 'Street and building regulation' [4, p. 9] introduced new standards about façade projections, projections on adjacent houses, 
building heights, categorizing 5 degrees for the roads, preparation of plans for new roads and fire-burnt areas. Later, the 'Building Law' of 1882 defined aspects of urban planning and practice. [4, p. 11]. Provisions deriving from the regulation and later from the building law were implemented in Kosovo, as certain evidences from filed observations show. Although limited in number, building built in Kosovo during this period implement the required standards are provisions like height of buildings, construction technology and style.

\section{Archive documents as a tool for spatial-architectural analysis and interpretation}

Implementation of Tanzimat Reforms in city planing and architecture took place not only in the centers of Vilayets like Shkodra, Manastir (Bitolja), Prishtina, etc, but also in smaller centers in a local level, respectively, in centers of Nahiyes.

Architecture of government buildings built in centers of Vilayets and Nahiyes in Kosovo, which have been preserved today represent the most significante material evidence of modernization tendencies of the period. On the other hand, street infrastructure and other urban activities in cities of Kosovo are difficult to identify due to extensive post-WWII urban reconstructions, which left almost no traces from urban activities undertaken after the Tanzimat Reforms. While no research was done in documentation and interpretation of street infrastructure and other urban activities in cities of Kosovo during late $19^{\text {th }}$ century, written material about the architecture of public building from this period is very limited and mostly presented in the form of short descriptions in the Database of cultural heritage of Kosovo [5]. As Harmuth $[6$, p. 21] confirms, very little is known about architecture realized in the Balkan states during the Ottoman period, mainly due to the fact that this region is perceived as periphery in relation to other major centers in the Empire or in Europe. As a result of absence of a written urban history of this period, Kosovo cities face difficulties in documenting their historical and cultural continuity.

Two cities belonging to the territory of present-day Kosovo used to be Centers of Vilayet: Prizren was the center of the Vilayet of Prizren from 1868 to 1874, and Prishtina was the center of the Vilayet of Kosovo from 1878 to 1888 (from 1888 to 1912 the center of the Vilayet of Kosovo moves to Skopje due to the pressure of Albanian riots against the Turkish authorities). The paper focues in those two centers, namely, Prizren and Prishtina, and analysis modernization specificities in terms of urban and architectural development, design and style, that were introduced after the Tanzimat reforms, which appart from being in comformity with the needs of the new governance system, they document the influence of the western European modernization of the period.

The paper uses original Ottoman Archive documents retrieved from Premiership Ottoman Archives (POA) by the first author, in the context of the agreement on cooperation between the State Archive of Kosovo and the State Archive of the Ottoman archives in Istanbul signed in 2004. The importance of the Ottoman Archive is furthering research on the historical aspect of architecture and the city has been already recognized by scholars [7]. Interpretation and analysis of archive documents are 
therefore seen as an important tool for understanding the beginnings of modernization of Kosovo in terms of urban and architectural development in late $19^{\text {th }}$ century, in line with other Balkan countries. Cartographic archive documents, sketches drawings of building designs, and original photos retrieved from POA by the first author and presented for the first time in this paper, are used in order to document the original plans and to analyze modernization trends in street infrastructure and architecture of public buildings in Kosovo. More specifically, the paper interrogates architectural style and street modernization tendencies in Kosovo during the Tanzimat period through the example of government buildings, namely central government buildings in Prishtina and Prizren (Hükümet Konaği) and the typology of local government buildings, as well as the new street network in the Vilayet of Prizren, in order to shed light to spatial and architectural development trends and tendencies during the $19^{\text {th }}$ century. This is important not only in terms of better understanding Kosovo's urban history, but also for establishing a structured critical comparison of the various historical and stylistic periods in architectural development, in order to promote the future planning of cities [8].

\section{Modernization of architecture and street infrastructure in Kosovo during late $19^{\text {th }}$ century}

\subsection{Architecture of government buildings}

The new system introduced with the Tanzimat Reforms brought along new building typology and construction style. Government buildings, as previously mentioned, begun to be constructed in the centers of Vilayets. Because they aimed to exhibit the strength of the Empire, these buildings gained a great importance [1, p. 943]. Influenced mainly by French architecture of the $19^{\text {th }}$ century, government buildings were design in a classical style, often showcasing some neo-baroque elements such are double entry stairs on the main façade. In general, architecture of government buildings had a typical spatial architectural structure: the number of floors is usually up to four floors (basement, ground floor, first and second floor), symmetrically placed windows with more or less prominent frame and pilasters on the main façade, as well as a rather light clasissical ornamentation.

The largest building constructed in the Vilayet of Kosovo during the period between 1878 and 1912 is the government building (Hükümet Konağı) in Prishtina, today the building of the National Museum of Kosovo. From the photo published in the Official Year Book of Kosovo Province of the Ottoman Empire in 1896, and retrieved from POA [9, p. 393], it can be concluded that the building was built between 1886, which is the year when Prishtina became the center of the Kosovo Vilayet, and 1896 being the year of the publishing of the Almanah. The picture of the buiding (Fig. 2a) shows a moderate Classical order and composition, seen elswere in the western countries.

The year of construction 1885/86 has been recently added in the description given in the Database of cultural heritage of Kosovo [5], most probably based on the assumption that 1886 is the year when Prishtina became center of the Vilayet. Authors argue that 1885 cannot be the year of construction based on the same assumption, but likewise, 
1886 may be the year when planning for the building was initiated. Until further archive information are retrieved in thew future, authors argue that the dates for the construction of the building, hence, should be indicative between 1886 and 1896 .

Original archive pictures retrieved from POA and presented in Fig. $2 b$ and Fig. $2 c$ are from a later date, respectively from 1911. What can be observed when comparing archive picture from the Official Year Book (Fig. 2a) and the archive pictures (Fig. 2b) is that some changes occurred in the roof of the building. More specifically the original pedimet is substituted with a balustrade, which confirms that the building was partially reconstructed after a fire incident, also documentet via archive documents which provide details on renovation expediture after building was damaged by fire [9].

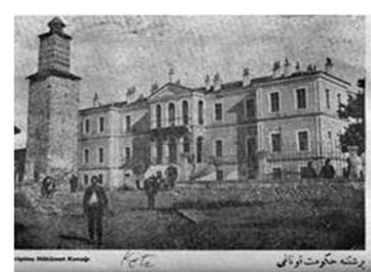

a)

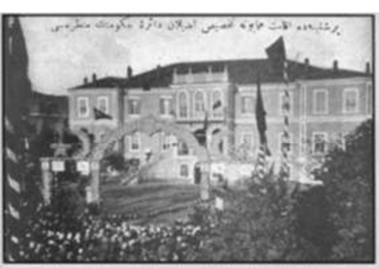

b)

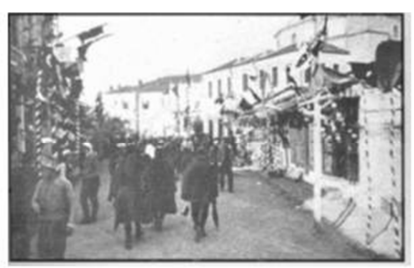

c)

Fig. 2. Government building in Prishtina (today the National Museum of Kosovo), a) Photo of the building taken between 1886-1896 [9, p. 333], b) photo of the building taken during the visit of Sultan Resat in 1912 [10, p. 514], c) photo of Pristina's main street outside the government building taken in 1912 [10, p. 512]

Original sketches of architectural drawings give us important information about new design rules and regulations adopted in late $19^{\text {th }}$ century. From the drawings it can be interesting that the design layout showcases the rules of symetry in plan and façade, and that the building is built in bricks and not in wood as previously, in order to comply with the newly adopted building regulation, espectially with regards to fire protection.

Since than, the building has undergone several restorations and each time, interventions were carried out without being based on the source documentation, specifically, architectural plans presented in Fig. 3a. The major intervention was done in 1975, when the building changed use into the Museum of Kosovo, in which context it required certain adaptations. Among major changes made to the building was the substitution of the existing roof with a higher loft of the mansard type, and the shape of the window: rectangular windows with pediments were substituted with arched windows, a situation which the building still maintains (Fig. 3b).

Archive schetches showing original architectural layouts and the main façade as it is presented in Fig $3 a$, authors argue, are of great importance for analysing past and possible future restorations in which case, the authenticity of the building should be considered. The well-established principle that emphasises the importance of conservation and restoration guidelines that would ensure the effective and efficient safeguarding of architectural heritage [11], would incorporate this aspect of scientific documentation which is one of key aspects in relation to the tetst of authenticity. 
Similar composition and architectural features used to have the government building in Prizren. The building today does not exist, and due to the lack of source documentation cultural heritage institutions in Kosovo and the Prizren citizens in general were uncertain about the existance of the building, until original photos were shown by the author of this paper. Through the original picture presented in Fig. 4 document the existence of a government building in Prizren, which most probably served as the headquarter of the Vilayet of Prizren between 1868 and 1874.
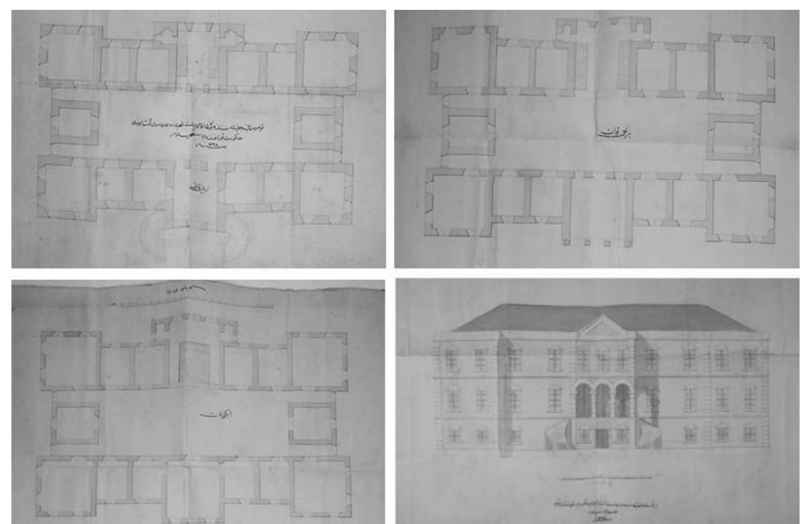

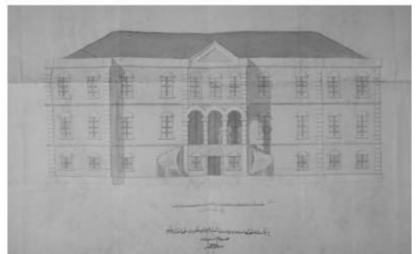

a)

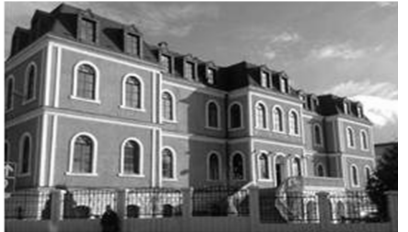

b)

Fig. 3. The Government Building in Prishtina, (Hükümet Konaği), a) original archive sketches of architectural drawings [10, p. 49], b) View of the building in 2017(source: Authors)

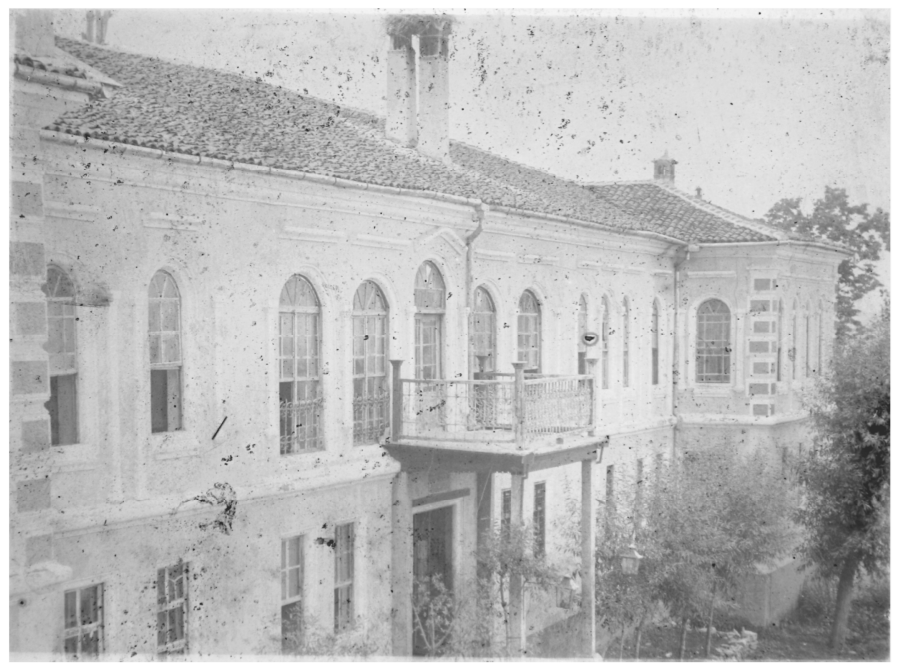

Fig. 4. Archive photo of the demolished Government Building in Prizren, which served as headquarter of the Vilayet of Prizren. [10, p.13] 
Despite similarities with the building in Prishtina in terms of style, simetry in layout and façade, the government building in Prizren had a public addressing balkony, an architectural feature found likewise elswere in the region and in Europe.

In order to contribute to the body of knowledge about this building in Prizren, the question of its location is further searched and documented in this paper, through the use of a map from 1913, produced by Milosavlevic and Stevovic in 12.02.1913 (Fig. 5), retrieved by author from archives of the Regional Center for Cultural Heritage in Prizren [12].

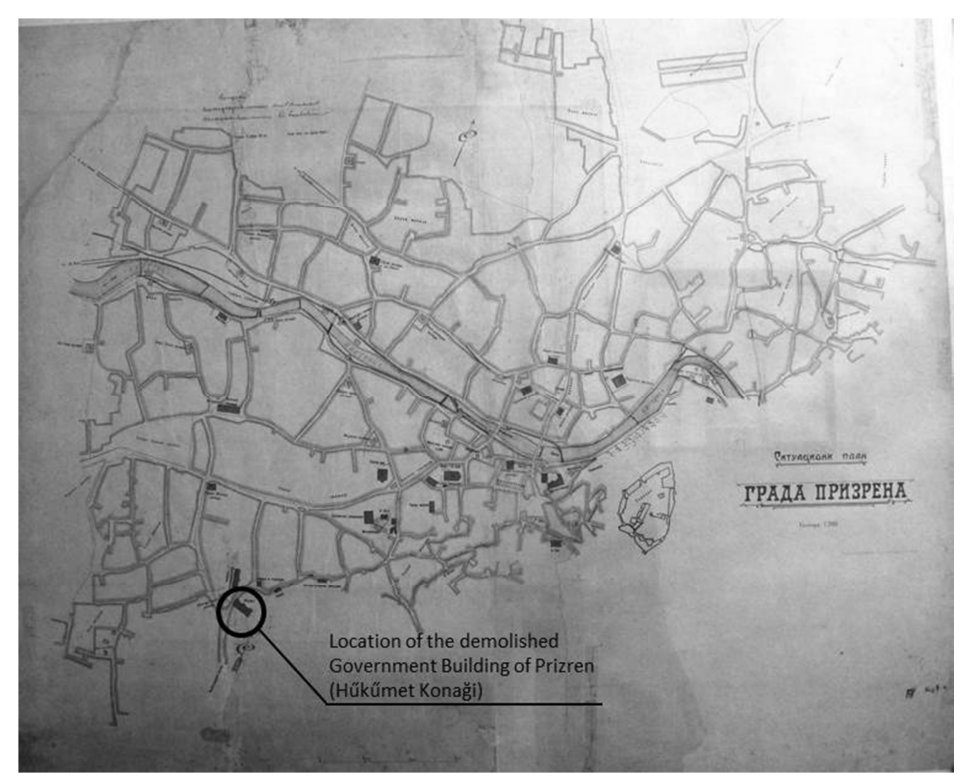

Fig. 5. Map of Prizren in 1913 [12]

Analysis of the map show that due to the compactness of the historic core of Prizren and most probably, due to respect for previous urban heritage from Medieval and Ottoman era, the $19^{\text {th }}$ century development occurred in the southeastern axis of the city. Among public buildings identified in the 1913 map, the government building of Prizren is identified and encircled by Authors also through interpreting the texts written next to the drawn layout of the building 'Ucumat' in Cyrillic letters. A rather simplified classical vocabulary was adopted in local government buildings as opposed to central government buildings in Prishtina and Prizren. In general, the architectural design for local administrations was typical as documented though original drawings from the publication about the Vilayet of Kosovo in archive documents [13, p. 226, p. 235], as it is shown in Fig. 6.

The picture in Fig. $6 a$ shows that local government buildings were smaller in mass and showcased simplicity in terms of style, while the building technology, materials and height standards are the same with those implemented in the central government buildings. Fig. $6 b$ shows the architectural plans for the local self-government building 
in Mitrovica, which does not exist today, symmetry in architectural appearance and façade was characteristic of the period, confirming that the tendencies of modernization were inclusive and generally found in all architectural buildings at the end of the $19^{\text {th }}$ century in Kosovo.

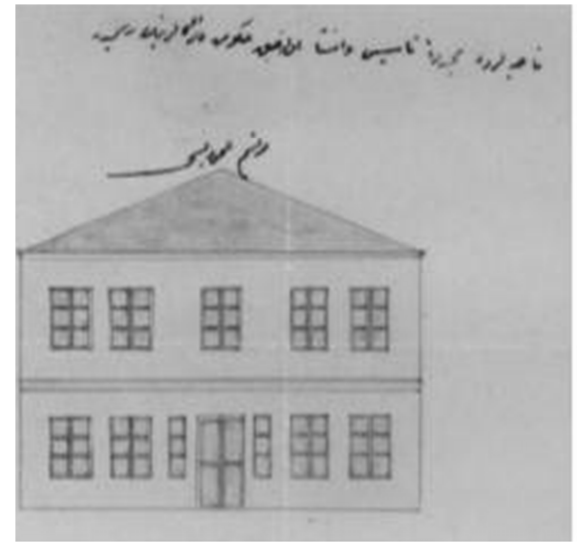

a)

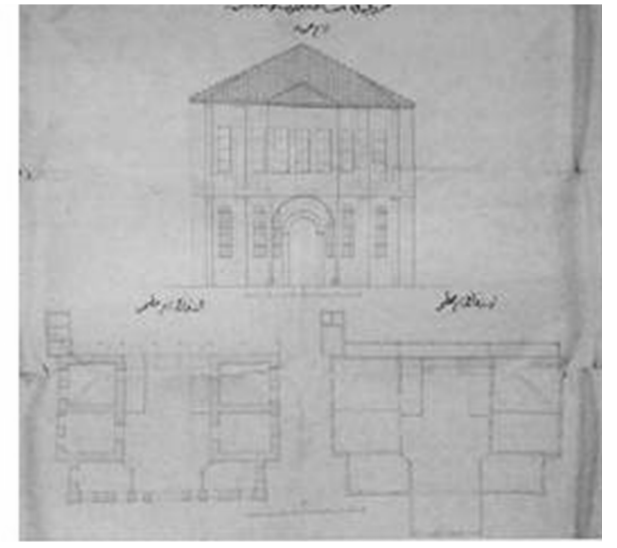

b)

Fig. 6. Local government buildings in $19^{\text {th }}$ century Kosovo, a) Sketch of typical façade of local government buildings drawn in 15 December 1897 [13, p. 226], b) Sketch plan of the government building in Mitrovica [13, p. 235]

\subsection{Street infrastructure}

Cartographic archive documents provide important information about the construction of new streets in Kosovo. Two original maps retrieved from POA document that during late $19^{\text {th }}$ century, one of major modernization efforts was to create the street network that aimed at the connection of major cities of the Vilayet. The map entitled 'Carte Du Vilayet Prisren' [10] drawn by Fischbach in September 1868, as indicated in the map, documents the existing network of streets in the territory of the Prizren Vilayet. In Fig $7 a$ also, with thick lines are marked segments of streets that were planned to be reconstructed and built anew. Graphical analyses of this map (Fig. 7b), insert that approximately 910 kilometers of streets were planned to be built or rebuilt. Three streets entering to Prizren were rebuilt in a wider profile, while the largest contribution was the rebuilding of the streets from Skopje to Nish and Shtip (Fig. 7b). It should be mentioned that Skopje was a large city which later, after Prishtina, became the center of the Kosovo Vilayet between 1888 and 1912. Investments in street network were implemented during the time when Prizren was the center of the Vilayet, which at the time was the largest Vilayets in the Ottoman part of Europe and included four large provinces: Prizren, Diber, Skopje and Nis [14, p. 109].

Another map from May 1870 entitled Carte des Routes nouvellement tracées dans Le Vilayet Prisren au Mois de Mail 1870', [10] drawn also by Fischbach, as indicated in the map, in Fig. 8 documents that new streets built during the $19^{\text {th }}$ century intended to connect other urban centers in the territory of Kosovo. The map also provides the list of 
bridges that would either need to be enhanced or built anew in order to adapt to the new streets. Graphical analyses of the map show that approximately 290 kilometers were built at the time of the drawing of the map, which suggests that this investment was realized in a matter of one year. The 1870 map indicates more accurately the rest of the 620 kilometers of planned new streets that were to be built in the course of the time.

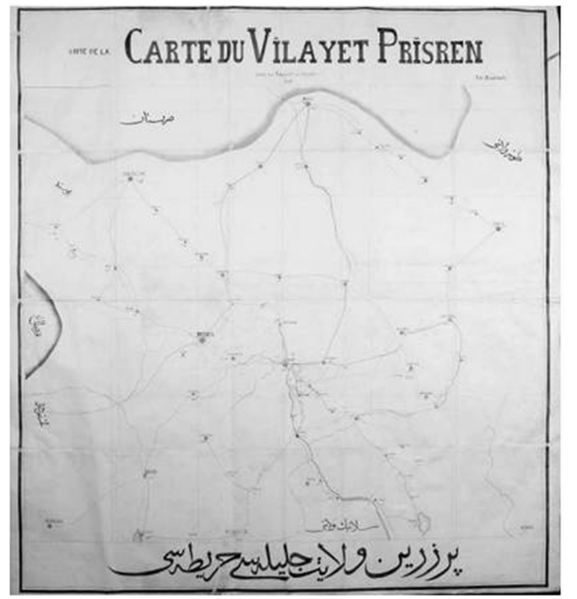

a)

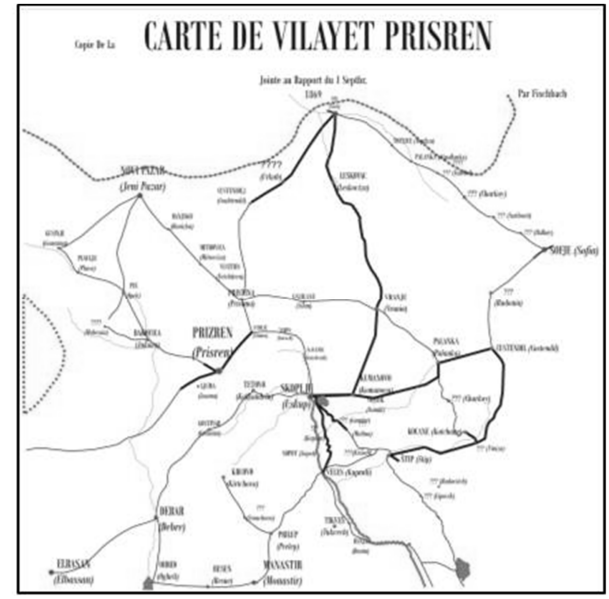

b)

Fig. 7. Street network indicating modernization of street segments in the Vilayet of Prizren in 1868, a) Original Map of the Vilayet of Prizren, September, 1868 [10, p. 308], b) graphical analysis of the original map indicating with thick line segments of streets planned to be modernized (Source: Authors plot, Vlora Navakazi)

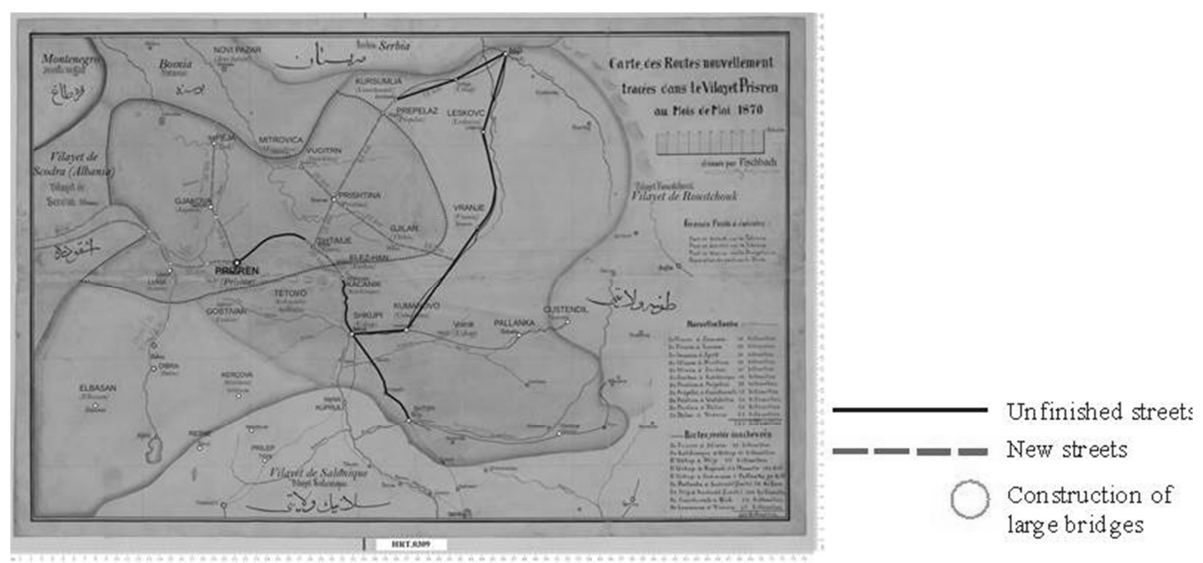

Fig. 8. Street network in the Vilayet of Prizren in 1870, a) Original map drawn by Fischbach [10, p. 309], b) Graphical analysis of the original map indicating finished and unfinished streets at the time of the drawing of the map (Source: Authors plot, Vlora Navakazi) 
Figures of street lengths are provided in the right side of the original map drawn by Fischbach (Fig. 8) as well as are presented in the tabular form (Table I and Table II).

\section{Table I}

New streets built as of 1870 in the territory of the Vilayet of Prizren according to Fischbach 's Map [10]

\begin{tabular}{|r|l|r|}
\hline \multicolumn{2}{|c|}{ 'Nouvelles Routes' (new streets) according to Fischbach's Map in Fig. 8} & $\mathrm{~km}$ \\
\hline 1 & De Prisren a Jaquova (from Prizren to Gjakova) & 30 \\
2 & De Prisren a Louma (from Prizren to Lume) & 25 \\
3 & De Jaquova a Ipek (from Gjakova to Peja) & 30 \\
4 & De Stimia a Pristina (from Shtimje to Prishtina) & 25 \\
5 & De Stimia a Jenihan (from Shtimje to Elez Han) & 20 \\
6 & De Jenihan a Katchenique (from Elez Han to Kaçanik) & 10 \\
7 & De Pristina a Prepelaz (from Prishtina to Prepelaz) & 55 \\
8 & De Prepelaz a Courchoumli (from Prepelaz to Kursumlia) & 15 \\
9 & De Pristina a Voetchitrn (from Prishtina to Vuçitrn) & 20 \\
10 & De Pristina a Yhilan (From Prishtina to Gjilan) & 35 \\
11 & De Yhilan a Vrania (From Gjilan to Vranje) & 25 \\
\hline & Total & 290 \\
\hline
\end{tabular}

Table II

Unfinished (planned) streets to be built as of 1870 in the territory of the Vilayet of Prizren [10]

\begin{tabular}{|c|c|c|}
\hline \multicolumn{2}{|r|}{$\begin{array}{l}\text { 'Routes, restee inachevees' (Unfinished streets) according to Fischbach's Map } \\
\text { in Fig. } 8\end{array}$} & \multirow{2}{*}{$\mathrm{km}$} \\
\hline 1 & De Prisren a Stimis (from Prizren to Shtimje) & \\
\hline 2 & De Katchenique a Uskup (from Kaçanik to Skoplje) & 30 \\
\hline 3 & De Uskup a Stip (from Skoplje to Stip) & 65 \\
\hline 4 & De Uskup a Kuptuli et a Monastir (from Skoplje to Kuptuli to Manastir) & 130 \\
\hline & De Uskup a Comanova \& Pallanka (from Skoplje to Kumanova \& & 90 \\
\hline 5 & Pallanka) & \\
\hline 6 & De Pallanka a Kustendil (limite) (from Palanka to Çustendil; limited) & 30 \\
\hline 7 & De Stipa a Kustendil (limite) (from Shtip to Çustendil; limited) & 100 \\
\hline 8 & De Courchoumli a Nis (from Kursumli to Nish) & 70 \\
\hline \multirow[t]{2}{*}{9} & De Comanova a Vrania (from Kumanovo to Vranja) & 60 \\
\hline & Total & 620 \\
\hline
\end{tabular}

\section{Conclusions}

Architecture and street infrastrucutre of the late $19^{\text {th }}$ century created during the Tanzimat Reforms represents one of the most fragile layers of the built heritage in Kosovo in terms of both, survived number of buildings and root tracks, mainly due to subsequent phases of urban development, as well as the lack of consistent historical interpretation. As a result, Kosovo cities face difficulties in documenting their historical and cultural continuity but more importantly, they lack interpretation on the 
modernization tendencies that occurred during late $19^{\text {th }}$ century, in line with other parts of the Late Ottoman Empire territories in the Balkan. Several buildings, and especially the typology of government buildings, which still stand today, witness these tendencies.

Yet, lack of original archive documentation until now has impeded scientific approach to architectural analysis and the documentation of architectural authenticity, including street network analysis, which this paper has tried to contribute through the use of original drawings and photos retrieved from the POA.

The need for a reinterpretation of architectural structures and modernization of street network dating back to the late $19^{\text {th }}$ century, no matter whether they still stand or were destroyed over the course of time, is essential for analysing past and possible future restorations and for establishing a continuity of historic interpretation and future planning development. Original sketches of architectural drawings and photos of public buildings in Prizren and Prishtina, former centers of Vilayets in the territory of Kosovo, as well as of the street networks planned and implemented during the late $19^{\text {th }}$ century, give us important data on the modes which aimed at connecting settlements in Kosovo, and on the type of architecture, which was introduced in urban centers and was build according to new standards in terms of building height, location, construction technology and architectural style. Studies of these features through the use and analysis of original visual archival documents, in which this paper has tried to contribute, are of great importance for the advancement of scientific research in the field of architecture and urbanism of Kosovo.

\section{References}

[1] Yazici N. Government office buildings in Trabzon Province from the Tanzimat era to the Republic Period, (in Turkish) Uluslararası Sosyal Araştırmalar Dergisi, Vol. 1, No. 5, 2008, pp. 943-959.

[2] Çelik Z. The remaking of Istanbul: portrait of an Ottoman city in the nineteenth century, Berkeley, University of California Press, 1993.

[3] Beyhan B., Uguz S. Planning as a tool for modernization in Turkey: The case of Herman Jansen's plan for Mersin, Journal of the Faculty of Architecture, Middle East Technical University Vol. 29, No. 2, 2012, pp. 1-34.

[4] Gençer C. I., Çokugras I. Regulation of urban space in the Ottoman State: The case of Istanbul (1820-1900), Megaron, E-Journal, Faculty of Architecture, Yildiz Technical University, Vol. 11, No. 1, 2016, pp. 1-14.

[5] Database of Cultural Heritage of Kosovo, https://dtk.rks-gov.net/tkk_objekti en.aspx?id=8815 (last visited 1 October 2018).

[6] Hartmuth M. The history of center-periphery relations as a history of style in Ottoman provincial architecture, In: Maximilian Hartmuth, (Ed) Centers and peripheries in Ottoman architecture: Rediscovering a Balkan Heritage, Report Series No. 9, 2010, http://chwb.org/bih/wp-content/uploads/sites/5/2015/02/Centres-and-peripheries-inOttoman-architecture-Rediscovering-a-Balkan-heritage.pdf (last visited 1 October 2018)

[7] Farooqi N. R. An overview of Ottoman archival documents and their relevance for medieval Indian history, The Medieval History Journal, Vol. 20, No. 2, 2017, pp. 192-229.

[8] Wettstein D. Historical analysis of regional planning of Balaton, Pollack Periodica, Vol. 8, No. 1,2013, pp. 141-152.

[9] Ağanoğlu H. Y. Official Yearbook of Province of Kosovo, (in Turkish), İstanbul, 2000. 
[10] Ottoman Turkish documents from the Premiership Ottoman Archives, POA, (in Turkish) Istanbul, retrieved by Vlora Navakazi, Istanbul, 2008.

[11] Nushi V., Jashari-Kajtazi T. The use of specific principles and guidelines for effective and efficient restoration of cultural heritage buildings; case study Jashar Pasha Mosque in Prishtina, Pollack Periodica, Vol. 13, No. 2, 2018, pp. 219-229.

[12] Regional center for cultural heritage of Prizren, retrieved by Vlora Navakazi, year 2008.

[13] Sarınay Y., Budak M., Bayır O., İzgöer A. Z., Ağanoğlu H. Y. Vilayet of Kosovo in Ottoman archive documents, (in Albanian and Turkish), İstanbul, T. C. Başbakanlık (Ed.) Devlet Arşivleri Genel Müdürlüğü, Osmanlı Arşivi Daire BaşkanlığI, No. 87, 2007, pp. 226-235.

[14] Haskuka, E. Historical-geographical analysis of urban functions of Prizren, (in Serbian), Gjakovica, 1985. 